\title{
Corporate Governance, Principal-Principal Agency Conflicts, And Disclosure
}

Chiraz Ben Ali, IPAG Business School, France

\begin{abstract}
This study investigates the relation between corporate governance and disclosure quality in a context of principal-principal conflicts and poor investor protection. Overall, the empirical results suggest that minority expropriation risk harms disclosure quality. Specifically, we find that disclosure quality is negatively associated with ownership concentration, major shareholder voting rights, the existence of double voting rights, and family control. The results obtained also evidence a positive relationship between disclosure quality and the existence of executive stock option plans giving support that this mechanism plays a key role in corporate transparency.
\end{abstract}

Keywords: Corporate Governance; Disclosure; Principal-Principal Conflicts

\section{INTRODUCTION}

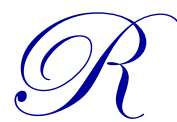

ecent years have seen a spate of regulatory action for the development of corporate governance mechanisms and disclosure in response to financial scandals. Most prior research examining the relationship between disclosure and corporate governance has concerned the USA (Nagar et al., 2003; Ali et al., 2007), a country where investors are highly protected and ownership is dispersed (La Porta et al., 2000), and as a result the focus has mainly been on the agency conflict between managers and shareholders (Type I agency conflict). However, recent studies show that ownership concentration is prevalent in most economies, for instance France, and the main agency conflict is in fact between controlling and minority shareholders (Type II agency conflict called also principal-principal conflict) (Shleifer \& Vishny, 1986; Faccio \& Lang, 2002).

This paper investigates whether firm-level corporate governance mechanisms supplement regulation to protect minority shareholders. We focus on the impact on corporate transparency of different corporate governance mechanisms such as the proportion of independent directors in the board (Forker, 1992; Chen \& Jaggi, 2000), the board size, the CEO duality leadership (Forker, 1992; Ho \& Wong, 2001), ownership structure, and shareholder relationships (Ho \& Wong, 2001; Chau \& Gray, 2002). The French context is worth studying for many reasons: 1) France is a country which has been used as a typical representative of a weak investor protection country family (La Porta et al., 1999) leading to ownership concentration; 2) many French listed firms are controlled and managed by families, providing more opportunities to expropriate minority shareholders; 3) French regulation allows the use of double voting rights: this enables controlling shareholders to hold voting rights in excess of their cash flow rights, and exacerbates Type II agency conflict (Faccio \& Lang, 2002).

Using a logistic regression on a sample of 81 non-financial French listed firms for the year 2004, we find a negative relationship between disclosure quality and (1) ownership and control concentration, (2) family control and (3) double voting rights. We conclude that Type II agency conflicts negatively influence disclosure quality. With high ownership and control concentration, controlling shareholders are less reliant on minority shareholders and may expropriate them, particularly when their actions remain unpunished because of institutional context weakness. Consequently, controlling shareholders have fewer incentives to disclose information and will try to retain it to avoid minority contests. Interestingly, however, our result on the relationship between family control and disclosure of French firms contradicts the findings of Ali et al. (2007) in the US context, suggesting that Type II conflict is more severe in France (La Porta et al., 2000). We find - perhaps surprisingly - no evidence of the influence of board characteristics on disclosure quality. Finally, the regression results show a positive relationship between disclosure quality and executive stock option plans. We suggest that executive stock option plans protect minority shareholders 
from expropriation by controlling shareholders, thereby compensating for the deficiencies in regulation to protect investors.

Our study contributes to the existing literature by providing new evidence on the growing agency conflict between controlling and minority shareholders while prior studies focus on manager-shareholder agency conflict (Barros et al., 2013). Our research also incites regulators to pay more attention to principal-principal conflicts. Present French regulations on corporate governance focus on manager-shareholder agency conflict, whereas the main agency conflict in France is in fact the conflict between controlling shareholders and minority shareholders.

The remainder of this paper is organized as follows. Section two reviews prior literature and presents the hypothesis development. Section three provides the research design. Results and conclusions are reported in sections four and five respectively.

\section{LITERATURE REVIEW AND HYPOTHESIS DEVELOPMENT}

Code law countries (such as France) offer weak investor protection compared to common law countries (La Porta et al., 1999). Corporate governance plays a key role to safeguard the financial reporting process (Bassett et al., 2007). Hence, corporate governance mechanisms, at the firm-level can supplement weakness of the country-level regulation to protect investors. The corporate governance attributes examined in this study are board characteristics (board size, proportion of independent directors in the board, unitary leadership structure - where the same person is CEO and chairman of the board), existence of executive stock options, and ownership structure.

\subsection{Corporate Disclosure and Minority Expropriation}

Previous studies point out that widely-held firms suffer from more severe manager-shareholder conflict than their counterparts; consequently, the demand for public information is higher (Gelb, 2000; Chau \& Gray, 2002). However, in a context of ownership concentration (for instance France) agency conflicts result more from conflicts between controlling shareholders and minority shareholders (principal-principal problem) (Fan \& Wong, 2005), and therefore disclosure should be affected differently. Because of their proximity to management, controlling shareholders can obtain private information (Johnson et al., 2000) and are therefore reluctant to publicly disclose information to avoid minority contests. Also, Fan and Wong (2002) find that controlling shareholders report accounting information for self-interested purposes, which results in less credibility in reported earnings. Similarly, Attig et al. (2006) posit that controlling shareholders have incentives to minimize and delay corporate disclosure. Lower and/or later disclosure helps controlling shareholders to increase the chance of executing their plans or to ensure minority shareholders' decisions are based on inadequate information (Attig et al., 2006). Thus, disclosure quality should be poor in firms with high ownership concentration. We state the first hypothesis:

H1: There is a negative relationship between disclosure quality and ownership concentration.

Controlling shareholders hold a high percentage of voting rights; they can therefore easily control the firm, and it is their disclosure strategy which leads to poor disclosure quality. Control concentration creates an entrenchment problem that allows controlling owners' self-dealings to go unchallenged internally by boards of directors or externally by takeover markets (Fan \& Wong, 2005). Also, due to the entrenchment effect that comes with control of the firm (Morck et al., 1988), controlling shareholders' decisions deprive minority shareholders of their information rights particularly in a context of weak legal system (Fan \& Wong, 2002). We present the following hypothesis:

H2: There is a negative relationship between disclosure quality and controlling shareholder voting rights.

The non-respect of the "one share one vote" rule in France (via double voting rights for instance) confirms weak investor protection in France (La Porta et al., 2000) and gives controlling shareholders voting rights in excess of their cash flow rights (La Porta et al., 2000; Fan \& Wong, 2005). Agency theory argue that the principal-principal problem resulting from the lack of convergence between the interests of controlling shareholders and those of minority investors is magnified when there is a discrepancy between cash flow and control rights (Boubaker \& 
Sami, 2011; Liu \& Magnan, 2011). For instance, Attig et al. (2006) find that stocks with greater deviation between ultimate control and ownership have a larger information asymmetry component in their bid-ask spread, suggesting poor disclosure quality in these firms. This result is also consistent with Schmid (2009) who observe that the deviation of control from ownership is associated with more selfish behavior by the ultimate shareholder. Hence, we pose the following hypothesis:

H3: There is a negative relationship between disclosure quality and the separation between voting rights and cash flow rights.

France has a higher proportion of family-owned and controlled companies than Anglo-American countries: more than $50 \%$ of French firms are controlled by family groups (Faccio \& Lang, 2002). In family firms, family members actively participate in the management of the firm and serve as directors on their board (Yoshikawa \& Rasheed, 2009; Ho \& Fei, 2013). They therefore have private information to assess the return on their investment. Comparing to non-family firms, family firms need less external financing and consequently, external information demand is low. Thus, consistent to the information financing need hypothesis, family firms have less incentive to disclose (Chau \& Gray, 2002; Yoshikawa \& Rasheed, 2009).

Other studies evidence that compared to non-family firms, family firms face less severe managershareholder conflict, but more severe principal-principal conflict (Ali et al., 2007; Chen et al., 2008; Ho \& Fei, 2013). These characteristics are likely to influence disclosure quality. First, because of less separation between ownership and management, family firms present lower Type I agency conflict, less information asymmetry and better disclosure quality. Second, when the controlling shareholder is a family, it has more strong incentives to expropriate minority shareholders than a widely held corporation because private benefits of control are not diluted among several independent owners ultimately (Villalonga \& Amit, 2006). Thus, Type II agency conflict is higher in family firms. Also, family shareholders can easily extract private benefits with the help of a board dominated by family members that can strongly influence its decisions (Hope et al., 2012). Consequently, they have incentives to limit disclosure in order to continue to easily expropriate private benefits.

To summarize, difference in the quality of disclosure between family and non-family firms would depend on the difference in the severity of their Type I and Type II agency problems. For instance, Chen et al. (2008) examine the voluntary disclosure practices of family firms and find that compared to non-family firms, family firms provide fewer earnings forecasts and conference calls, whereas Ali et al. (2007) find a positive relationship between disclosure and family ownership suggesting that Type I conflict exceeds Type II conflict in the USA. The characteristics of French family firms raise interesting questions about their corporate disclosure practices. We suggest that French family firms face more severe Type II conflicts than their American counterparts and that these conflicts exceed Type I agency conflicts. We therefore state the following hypothesis:

H4: Family-controlled firms provide poor disclosure quality.

\subsection{Corporate Disclosure and Board Characteristics}

Adoption of internal control devices such as independent directors, small-sized boards, and separation of the roles of chairman and chief executive officer reduce agency conflicts (Baek et al., 2009) and could therefore reduce the benefits to be derived from withholding information. Consequently, such measures help to improve disclosure quality.

Inclusion of independent directors on corporate boards is a question that has received increasing attention from French regulations (Vienot report (1995), Bouton report (2002)). Chen and Jaggi (2000) present two main arguments in support of independent directors. First, independent directors advise corporate boards on strategic decisions (for instance disclosure decisions). Second, boards with a higher proportion of independent directors exercise greater control and greater monitoring over managerial decisions (Fama \& Jensen, 1983; Barako et al., 2006); while boards dominated by non-independent directors, are more aligned with the manager which could harm shareholder interests and firm transparency. It is also assumed that independent directors have incentives to exercise their role of decision control in order to maintain reputational capital (Fama \& Jensen, 1983; Baker et al., 2011). 
Inclusion of independent directors on boards is thus expected to improve the firm's compliance with disclosure requirements, which in turn, will enhance the comprehensiveness and quality of disclosure. Previous studies show a positive relationship between disclosure quality and the proportion of independent directors on the board (Chen \& Jaggi, 2000; Barako et al., 2006; Nelson et al., 2010; Barros et al., 2013). Also, Patelli and Prencipe (2007) argue that independent directors represent an important control mechanism to protect the interests of noncontrolling shareholders in the presence of a dominant shareholder. Thus, this control mechanism should counterbalance lobbying by non-independent directors who are more aligned with controlling shareholders. We state hypothesis H5:

H5: There is a positive relationship between the proportion of independent directors and disclosure quality.

When the CEO is also the chairman, the board cannot be an effective means to control management decisions, because obviously it is difficult to go against top management decisions when the chairman of the board is also part of the top management. Previous research has argued that CEO duality leadership harms shareholder's interests because it leads to greater managerial dominance since that individual is more aligned with management than with shareholders (Mak \& Li, 2001; Hope \& Thomas, 2008). Ho and Wong (2001) assert that firms with CEO duality leadership enable the person who occupies both roles to withhold unfavourable information. Also, Forker (1992) finds that CEO duality leadership is negatively associated with disclosure quality. Based on these arguments, we propose the following hypothesis:

H6: There is a negative relationship between CEO duality leadership and disclosure quality.

While numerous studies have investigated the effects of board size on board effectiveness, empirical evidence is rather inconsistent. One explanation is the existence of two opposite directions (Jensen, 1993). First, large boards are more likely to attract directors for reputation issue, and have independent directors with corporate or financial experience (John \& Senbet, 1998; Xie et al., 2003). Thus, a larger board might be better to enhance corporate governance. Second, this benefit may be offset by the incremental cost of poorer communication and decision-making inefficiencies that are often associated with large groups (Bantel \& Jackson, 1989). Thus, larger board size can reduce the board's ability to resist CEO control (Cheng \& Courtenay, 2006). Empirically, Yermack (1996) finds that firm valuation is negatively related to the size of the board. Consistent to these findings, Eisenberg et al. (1998) show a negative correlation between firms' profitability and board size in a sample of small and midsize Finnish firms. Thus, there seems no theory of prior evidence to find the association between board size and disclosure quality. Hypothesis $\mathrm{H} 7$ is thus stated in the null form:

H7: There is no relationship between board size and disclosure quality.

\subsection{Corporate Disclosure and Executive Stock Option Plans}

Managers who benefit from stock option plans are presumed to be concerned about the economic consequences of their decisions, since their personal wealth depends on the value of their firm. Stock-price-based incentives in the form of stock-options mitigate the manager-shareholder agency problem.

Disclosure enhances stock liquidity and firm value (Iatridis \& Alexakis, 2012), and therefore managers interested in exercising their stock options have incentives to improve disclosure so as to profit from these benefits. Empirically, Nagar et al. (2003) examine a sample of 1129 firms during 1992-1995 and evidence a positive relation between managers' disclosure activities and their stock-price-based incentives. They show that firms' disclosures are positively related to the proportion of CEO compensation affected by share price, and suggest that shareholders deliberately use stock options to reach their target level of disclosure. We thus hypothesize that firms offering their managers stock option plans should have good quality of disclosure, and our hypothesis $\mathrm{H} 8$ is as follows:

H8: There is a positive relationship between disclosure quality and the existence of executive stock option plans. 


\section{RESEARCH METHODOLOGY}

\subsection{Sample and Data}

Our initial sample consists of all French listed firms included in the SBF 120 index in 2004. As in prior studies, we exclude financial firms (SIC codes 6000-6999) since they operate in an environment where disclosure is more likely to be the result of specific legal and regulatory requirements rather than a response to agency conflict concerns (19 observations). We discard all firms with missing financial or corporate governance data (20 observations). The final sample thus comprised 81 companies. Board and ownership data, as well as stock options data, were hand-collected from firms' annual reports, available from the AMF (financial market authority)'s website. Financial data are retrieved from the Compustat database. variable.

We chose the SBF120 firms and the year 2004 because of information availability on the disclosure quality

First, disclosure quality is a very difficult variable to measure in the French context. In the USA, a number of organizations assess firms' disclosures, for example the AIMR/CFA (Association of Investment Management Research, now the CFA institute), and the FAF (Financial Analysts Federation Corporate Information Committee). These organizations publish disclosure scores for a wide range of companies over a long period. Unfortunately, there are no similar data available for France. Also, disclosure score made by authors could suffer from subjectivity (choice of items list and items weight) (Marston \& Shrives, 1991).

Second, previous studies in France use the AGEFI best annual report prize to measure disclosure quality (Labelle \& Schatt, 2005). Similarly, we use the AGEFI prize to select firms with good disclosure quality. The AGEFI study awarded prizes to French listed companies for their quality of disclosure, measured by listing segment (e.g. alternative, and over-the-counter markets), disclosure channel (e.g. annual reports) and type of operations on the market (e.g. first-time listing). As prior research shows a positive relationship between the whole corporate disclosure level and the level of information included in the annual report (Lang \& Lundholm, 1993), we focus on AGEFI best annual report prize.

AGEFI study presents a short list of companies from the SBF120 index that were nominated for the best annual report prize. Following prior study (Labelle \& Schatt, 2005), we consider that shortlisted firms present good disclosure quality. Our dependent variable DISCL equals 1 if the firm was shortlisted and 0 otherwise.

Since the first adoption of IFRS in 1/1/2005 for consolidated financial statements affects disclosure quality, we exclude all the years after 2004. Also, the annual report prize was discontinued after 2008 and the data from 2005-2008 are not available. Our choice of the year 2004 is justified by the fact that it is the last year available that takes into account the consequences of the NRE act (2001) and the LSF act (2003) (corporate governance regulation).

\subsection{Model}

We use the following regression model to test our hypotheses:

DISCL $_{i}=\beta_{0}+\beta_{1}$ HERFI $_{i}+\beta_{2}$ VOT1 $_{i}+\beta_{3}$ VOT $_{i}+\beta_{4}$ DBLE $_{i}+\beta_{5}$ FAM $_{i}+\delta_{1}$ BOARD $_{i}+\delta_{2}$ INDEPEND $_{i}+\delta_{3}$ DUAL $_{i}$ $+\delta_{4} \mathrm{SO}_{\mathrm{i}}+\sum_{j=1}^{5} \chi_{\mathrm{j}}$ FSCONTROL $+\varepsilon_{\mathrm{i}}$ :

Where DISCL measures disclosure quality and FSCONTROL denotes firm-specific variables. All variables are defined in Table 1. 
Table 1: Variable Definitions

\begin{tabular}{|c|c|c|}
\hline Variable & Empirical Definition & Data Source \\
\hline \multicolumn{3}{|c|}{ Dependent Variable for Firm i } \\
\hline $\operatorname{discl}_{i}=$ & 1 if firm $i$ is shortlisted in the AGEFFI study, and 0 otherwise & AGEFFI Euronext study \\
\hline \multicolumn{3}{|c|}{ Test Variables for Firm i } \\
\hline herfi $_{i}=$ & Herfindahl index measuring ownership concentration & Annual report \\
\hline $\operatorname{vot} 1_{i}=$ & $\%$ of voting rights of the largest shareholder & Annual report \\
\hline $\operatorname{vot} 2{ }_{i}=$ & $\%$ of voting rights of the $2^{\text {nd }}$ largest shareholder & Annual report \\
\hline dble $_{i}=$ & 1 if firm $i$ uses double voting rights, and 0 otherwise & Annual report \\
\hline $\operatorname{val}_{i}=$ & voting rights/cash flow rights of the largest shareholder (alternative measure) & Annual report \\
\hline $\operatorname{fam}_{i}=$ & 1 if the largest ultimate shareholder is a family, and 0 otherwise & Annual report \\
\hline independ $_{i}$ & $=\%$ of independent directors on the board & Annual report \\
\hline $\operatorname{direct}_{i}=$ & number of independent directors on the board (alternative measure) & Annual report \\
\hline $\operatorname{dual}_{i}=$ & 1 if the CEO is also chairman of the board, and 0 otherwise & Annual report \\
\hline board $_{i}=$ & number of directors in the board & Annual report \\
\hline stock $_{i}=$ & 1 if the firm offers executive stock options, and 0 otherwise & Annual report \\
\hline \multicolumn{3}{|c|}{ Control Variables for Firm i } \\
\hline listing $_{i}=$ & 1 if firm $i$ is listed on a foreign market, and 0 otherwise & Compustat \\
\hline $\mathrm{uscot}_{i}=$ & 1 if firm $i$ is listed on the US stock market, and 0 otherwise & Compustat \\
\hline $\operatorname{logasstot}_{i}=$ & natural log of total assets in thousands of Euros & Compustat \\
\hline $\operatorname{cac} 40_{i}=$ & 1 if firm $i$ is part of the CAC40 index, and 0 otherwise & Compustat \\
\hline $\mathrm{debt}_{i}=$ & leverage ratio & Compustat \\
\hline
\end{tabular}

\subsection{Descriptive Statistics}

Descriptive statistics are reported in Table $2 \mathrm{a}$ and Table $2 \mathrm{~b}$.

Table 2a: Descriptive Statistics of Continuous Variables

\begin{tabular}{|l|c|c|c|c|c|c|c|c|}
\hline & $\mathbf{N}$ & mean & sd & min & p25 & p50 & p75 & max \\
\hline Board & 81 & 10.827 & 3.794 & 4.000 & 8.000 & 11.000 & 14.000 & 17.000 \\
Independ & 81 & 0.431 & 0.210 & 0.000 & 0.313 & 0.444 & 0.600 & 0.750 \\
Herfi & 81 & 0.148 & 0.160 & 0.003 & 0.023 & 0.063 & 0.243 & 0.510 \\
Vot1 & 81 & 0.337 & 0.246 & 0.050 & 0.120 & 0.270 & 0.540 & 0.820 \\
Vot2 & 81 & 0.082 & 0.069 & 0.000 & 0.030 & 0.060 & 0.130 & 0.240 \\
Va1 & 81 & 1.217 & 0.271 & 1.000 & 1.000 & 1.050 & 1.360 & 1.800 \\
Debt & 81 & 0.225 & 0.136 & 0.010 & 0.120 & 0.230 & 0.310 & 0.460 \\
Asstot & 81 & 8181 & 1551 & 5920 & 6930 & 7960 & 9490 & 10970 \\
Direct & 81 & 4.815 & 2.757 & 0.000 & 2.000 & 5.000 & 7.000 & 10.000 \\
\hline
\end{tabular}

Table 2b: Descriptive Statistics of Categorical Variables

\begin{tabular}{|l|c|c|c|}
\hline & Variables & Observations & Frequency \\
\hline \multirow{2}{*}{ Discl } & Poor disclosure quality & 57 & 20.37 \\
& Good disclosure quality & 24 & 40.63 \\
\hline \multirow{2}{*}{ Dual } & No leadership duality & 33 & 59.29 \\
& Leadership duality & 48 & 49.38 \\
\hline \multirow{2}{*}{ Fam } & Non family-controlled & 40 & 50.62 \\
\hline \multirow{2}{*}{ Dble } & Family-controlled & 41 & 45.68 \\
\hline \multirow{2}{*}{ Stock } & No double voting right shares & 37 & 54.32 \\
& Double voting right shares & 44 & 39.51 \\
\multirow{2}{*}{ Listing } & No executive stock option plans & 32 & 60.49 \\
\hline \multirow{2}{*}{ Cac40 } & Executive stock option plans & 49 & 53.09 \\
& No foreign listing & 43 & 46.91 \\
\hline \multirow{2}{*}{ Uscot } & Foreign listing & 38 & 81.48 \\
& Non CAC40 firm & 66 & 18.52 \\
\hline
\end{tabular}


Descriptive statistics show that the majority shareholder's average percentage of voting rights is $33.7 \%$, and the average Herfindhal index is 0.148 . These high values prove that ownership and control are concentrated in French firms, in contrast to the American firms studied in most prior research, which have diffuse control and ownership. Our results are consistent with the findings of La Porta et al.(2000). We also find that 50.62\% of firms in the sample are controlled by families, which is similar to the findings of Faccio and Lang (2002). As expected, the descriptive statistics reveal that most of the sample firms display separation between voting rights and cash flow rights (54.32\% of our firms use double voting rights). We also calculate the dominant shareholder's voting rights in relation to his cash flow rights, and find that the voting rights of the dominant shareholder exceeds their cash flow rights by $21.7 \%$ on average. These results prove ownership concentration, the predominance of family-controlled firms, and the separation between ownership and control in France. We conclude that this context is appropriate to examine principal-principal conflicts (controlling vs. minority shareholders).

Among the sample of 81 firms, 24 firms were shortlisted for the prize, indicating that they offer good disclosure quality. These firms represent $29.63 \%$ of the total sample. Table $3 \mathrm{a}$ and Table $3 \mathrm{~b}$ present the characteristics of the two subsamples: firms with good disclosure quality and firms with poor disclosure quality.

Table 3a: Summary Statistics of the Dependant Variable

\begin{tabular}{|l|c|c|c|c|c|c|c|c|c|c|}
\cline { 2 - 11 } \multicolumn{1}{c|}{} & \multicolumn{9}{c|}{ DISCL $=\mathbf{1}$} & \multicolumn{4}{c|}{ DISCL $=\mathbf{0}$} \\
\cline { 2 - 12 } \multicolumn{1}{c|}{} & $\mathbf{N}$ & mean & sd & min & max & N & mean & sd & min & max \\
\hline Board & 24 & 12.000 & 3.502 & 7.000 & 18.000 & 57 & 10.351 & 3.824 & 4.000 & 16.000 \\
\hline Independ & 24 & 0.569 & 0.163 & 0.313 & 0.800 & 57 & 0.376 & 0.203 & 0.000 & 0.700 \\
\hline Herfi & 24 & 0.039 & 0.045 & 0.000 & 0.148 & 57 & 0.195 & 0.173 & 0.005 & 0.543 \\
\hline Vot1 & 24 & 0.148 & 0.092 & 0.020 & 0.290 & 57 & 0.414 & 0.250 & 0.060 & 0.830 \\
\hline Vot2 & 24 & 0.086 & 0.074 & 0.010 & 0.280 & 57 & 0.082 & 0.070 & 0.000 & 0.240 \\
\hline Va1 & 24 & 1.220 & 0.326 & 1.000 & 1.870 & 57 & 1.219 & 0.254 & 1.000 & 1.770 \\
\hline Debt & 24 & 0.258 & 0.131 & 0.040 & 0.460 & 57 & 0.213 & 0.140 & 0.010 & 0.500 \\
\hline Asstot & 24 & 8973 & 1464 & 6490 & 11250 & 57 & 7836 & 1480 & 5800 & 10570 \\
\hline Direct & 24 & 6.583 & 2.320 & 2.000 & 10.000 & 57 & 4.035 & 2.521 & 0.000 & 9.000 \\
\hline
\end{tabular}

Table 3b: Summary Statistics of the Dependant Variable

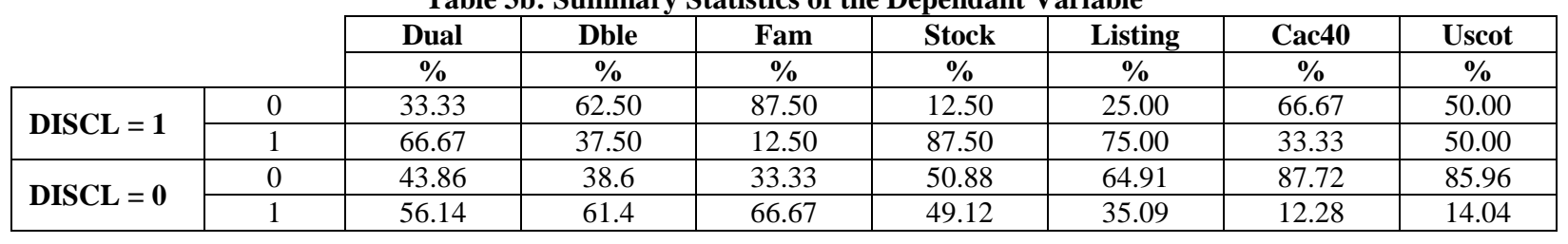

Many differences are observed between the two subsamples. Compared to firms with poor disclosure quality, firms with good disclosure quality are less controlled by families (12.5\% vs. $66.67 \%)$, use double voting rights less (37.5\% vs. $61.4 \%)$, have a higher proportion of independent directors on their boards $(56.9 \%$ vs. $37.6 \%)$ and lower ownership concentration (0.039 vs. 0.195$)$ and control concentration (14.8\% vs. $41.4 \%)$.

Table 4 discloses the correlation matrix for the dependent variable (discl) and the whole set of independent variables.

The correlation matrix shows that the independent variable (discl) is negatively and significantly correlated at $1 \%$ with ownership concentration (herfi), control concentration (vot1), and family control (fam), and positively and significantly correlated at $1 \%$ with board independence (independ), executive stock options (stock), size (logasstot), US and foreign listing (uscot and listing). The independent variable is also positively (respectively negatively) correlated at 5\% with cac40 (dble). The direction of correlations is consistent with our hypotheses. However, multivariate analysis must be run before reaching any conclusion on the relationships. 


\begin{tabular}{|c|c|c|c|c|c|c|c|c|c|c|c|c|c|c|c|c|}
\hline \multicolumn{17}{|c|}{ Table 4: Correlation Matrix } \\
\hline & 1 & 2 & 3 & 4 & 5 & 6 & $\begin{array}{l}7 \\
\end{array}$ & 8 & 9 & 10 & 11 & 12 & 13 & 14 & 15 & 16 \\
\hline (1) discl & 1 & & & & & & & & & & & & & & & \\
\hline (2) board & 0.18 & 1 & & & & & & & & & & & & & & \\
\hline (3) dual & 0.098 & $0.27^{* *}$ & 1 & & & & & & & & & & & & & \\
\hline (4) independ & $0.40 * * *$ & $0.19 *$ & -0.00 & 1 & & & & & & & & & & & & \\
\hline (5) herfi & $-0.44 * * *$ & -0.08 & -0.06 & $-0.40 * * *$ & 1 & & & & & & & & & & & \\
\hline (6) vot1 & $-0.48 * * *$ & -0.12 & -0.00 & $-0.44 * * *$ & $0.96 * * *$ & 1 & & & & & & & & & & \\
\hline (7) vot2 & 0.00 & 0.06 & -0.09 & -0.034 & -0.12 & -0.08 & 1 & & & & & & & & & \\
\hline (8) dble & $-0.22 * *$ & -0.12 & 0.15 & -0.097 & -0.04 & 0.08 & 0.08 & 1 & & & & & & & & \\
\hline (9) fam & $-0.49 * * *$ & $-0.24^{* *}$ & -0.07 & $-0.41 * * *$ & $0.27^{* *}$ & $0.36^{* * *}$ & 0.15 & $0.33^{* * *}$ & 1 & & & & & & & \\
\hline (10) va1 & -0.0150 & -0.01 & 0.07 & 0.08 & $-0.29 * * *$ & $-0.20 *$ & 0.06 & $0.73 * * *$ & 0.10 & 1 & & & & & & \\
\hline (11) stock & $0.36 * * *$ & $0.20 *$ & 0.15 & $0.31^{* * *}$ & $-0.35 * * *$ & $-0.33 * * *$ & 0.12 & 0.12 & -0.04 & 0.15 & 1 & & & & & \\
\hline (12) listing & $0.36 * * *$ & $0.31^{* * *}$ & 0.12 & $0.33^{* * *}$ & $-0.22 * *$ & $-0.26 * *$ & -0.02 & $-0.28 * *$ & $-0.46 * * *$ & -0.13 & 0.10 & 1 & & & & \\
\hline (13) debt & 0.15 & 0.11 & 0.11 & 0.10 & $-0.32 * * *$ & $-0.26 * *$ & 0.10 & 0.09 & 0.017 & 0.11 & $0.22 *$ & 0.10 & 1 & & & \\
\hline (14) logasstot & $0.32 * * *$ & $0.65^{* * *}$ & $0.20^{*}$ & $0.27^{* *}$ & -0.15 & $-0.22 * *$ & $-0.21^{*}$ & -0.14 & $-0.42 * * *$ & 0.06 & 0.12 & $0.45^{* * *}$ & 0.16 & 1 & & \\
\hline (15) cac40 & $0.24^{* *}$ & $0.38 * * *$ & $0.27 * *$ & 0.081 & $-0.20^{*}$ & $-0.22 * *$ & 0.02 & 0.05 & -0.16 & 0.12 & $0.25 * *$ & $0.19 *$ & 0.16 & $0.55^{* * *}$ & 1 & \\
\hline (16) uscot & $0.38 * * *$ & $0.26 * *$ & 0.12 & 0.13 & $-0.20^{*}$ & $-0.23 * *$ & -0.06 & $-0.22 * *$ & -0.18 & -0.10 & 0.05 & $0.55^{* * *}$ & 0.04 & $0.28 * *$ & 0.17 & 1 \\
\hline $\mathrm{N}$ & 81 & & & & & & & & & & & & & & & \\
\hline
\end{tabular}

$* \mathrm{p}<0.10, * * \mathrm{p}<0.05, * * * \mathrm{p}<0.01$

Board measures board size. Independ measures the \% of independent directors on the board. Herfi measures the ownership concentration and is calculated by the sum of the squared percentage shareholdings. Votl and Vot 2 are respectively the voting rights of the largest and second-largest shareholder. Val is the voting rights of the largest shareholder divided by the portion of shares held. Debt is the ratio of total debt to total assets. Asstot is the firm's total asset value. Direct measures the number of independent directors. Dual is a binary variable that portion of shares held. Debt is the ratio of total debt to total assets. Asstot is the firm's total asset value. Direct measures the number of independent directors. Dual is a binary variable that
equals 1 if the CEO is also the chairman of the board and 0 otherwise. Fam equals 1 if the largest shareholder is a family and 0 otherwise. Dble is a dichotomic variable indicating the existence of double voting rights. Stock is coded 1 if executives benefit from stock option plans and 0 otherwise. Listing equals 1 if the firm is cross-listed and 0 otherwise. Uscot equals 1 if the firm is US-listed and 0 otherwise. Cac40 equals 1 if the firm is part of the CAC40 index and 0 otherwise. 
from the existence of dual-class shares exacerbates Type II conflict and explains the negative effect on disclosure. However, the negative coefficient of the variable val is not significant. Thus we could not validate our third hypothesis.

As previously suggested, the impact of family control on disclosure reflects the difference between the respective effects of Type I and Type II agency conflicts (Chen et al., 2008). Similarly to Chau and Gray (2002), we find a negative and significant relationship between family control and disclosure quality, which confirms H4 ( $\beta=$ 2.184, p .016 in Model 1 and $\beta=-3.181, \mathrm{p} .004$ in Model 2). This result suggests that for family firms, the decrease in disclosure due to Type II agency conflict exceeds the increase in disclosure resulting from less severe Type I agency conflict. This result is the opposite of findings reported by Ali et al. (2007) on a sample of US firms. Thus, our results are consistent with La Porta et al. (2000), suggesting that French firms face more severe Type II agency conflict than their American counterparts.

Surprisingly, our results provide no evidence that the board characteristics influence disclosure quality (H5, H6, and H7). Nevertheless, our results are similar to previous studies that find no significant relation between disclosure level and board independence (Molz, 1988; Ho \& Wong, 2001), board size (Cheng \& Courtenay, 2006) or CEO duality (Cheng \& Courtenay, 2006). One possible explanation is the substitution effect of governance mechanisms (Williamson, 1983). Disclosure seems to make up for the ineffectiveness of a failing mechanism such as the separation of the two functions cited above, or independent directors.

With regard to the impact of executive stock options on disclosure quality, we find a positive and significant coefficient of the variable stock $(\beta=2.076, \mathrm{p} .025)$. We confirm therefore the existence of a positive relationship between disclosure quality and executive stock option plans: Hypothesis $\mathrm{H} 8$ is validated. This result is similar to prior literature (Nagar et al., 2003; Lakhal, 2007). We suggest that managers are motivated to enhance disclosure in order to increase profitability, growth, and liquidity (Iatridis \& Alexakis, 2012) and improve their wealth.

Finally, we find a positive relationship between US listing and disclosure quality, and no relationship between disclosure quality and cross-listing. We conclude that the American market is more demanding as regards to information than other markets. Firms listed on the American market are subject to very strict financial disclosure requirements.

\section{CONCLUSIONS}

Although the French legal context provides less investor protection than the American context (La Porta et al., 2000), many corporate governance laws have been enacted in recent years. First, the LSF Act (2003), similar to the Sarbanes-Oxley Act in the USA, required companies to report to the general shareholders' meeting on the organization of the board's work, internal control procedures and delegation of powers. Second, the NRE Act (2001) reinforced requirements on disclosure of shareholder agreements and encouraged disclosure of shareholder identities; it also enlarged the shareholder's right to information by eliminating the minimum number of shares needed to participate in the general meeting.

This paper examines whether the disclosure quality of French firms is a function of corporate governance mechanisms. It makes a useful contribution by testing this relationship in the light of two factors showing important institutional differences compared to previous studies, which have mainly concerned the US: ownership concentration (Faccio \& Lang, 2002) and poor investor protection (La Porta et al., 2000). These differences make French context interesting because it allows us to highlight a rarely-studied agency conflict: the conflict between controlling shareholders and minority shareholders (Type II conflict). This study thus adds to the growing principalprincipal conflict literature. This conflict has been less extensively examined in the accounting literature than Type I agency conflict (manager/shareholder conflict), once again because most prior studies have been conducted in common law countries, mainly the USA. Also and surprisingly, the few studies made in France focus on Type I agency conflict (Labelle \& Schatt, 2005; Barros et al., 2013) while the main conflict is the one between controlling shareholders and minority shareholders (La Porta et al., 2000). 
Our study supports the hypothesis that Type II agency conflict influence negatively disclosure quality, consistent with the fact that investors are not as well protected in code law countries (such as France) as in common law countries. Disclosure quality is shown to be weak in firms with both high ownership and voting rights concentration, and where controlling shareholders, mainly families, hold double voting right shares. Double voting rights help controlling shareholders to not bear all the consequences of their decisions, and therefore give them more opportunities to expropriate minority shareholders. This situation exacerbates principal-principal conflict and leads controlling shareholders to withhold information in order to avoid minority contests.

We find that family firms have poor disclosure quality consistent to prior results found in East Asia, a context characterized by ownership concentration and the dominance of family firms (Chen et al., 2008; Chau \& Gray, 2010). Nevertheless, these findings contradict the results of Ali et al. (2007) in the American context, suggesting that French family firms face higher Type II agency conflict than their American counterparts (La Porta et al., 2000). We also find that executive stock options protect minority shareholders' rights and result in better disclosure quality. As suggested before, we argue that corporate governance mechanisms are likely to supplement regulation to protect investor rights. In systems with weak legal investor protection, executive stock options could protect minority shareholders from controlling shareholder expropriation.

This study does however have some limitations. First, it was difficult to measure disclosure quality in France due to the absence of disclosure assessments similar to the FAF and AIMR disclosure scores in the US. We use the nominations for the AGEFI's best annual report prize as a binary dependent variable to measure disclosure quality, but this involves a lack of variability and reduces the choice of possible methodologies. Second, although we use many control variables in our regression, more control variables such as industry sector and growth ratio could be introduced to control for disclosure quality: we were unable to do this due to our small sample size. Also, controlling for endogeneity could enhance our model specification. Despite these limitations, our results provide a better understanding of the disclosure determinants related to corporate governance mechanisms, and may prove useful for standard-setters and regulators. This study calls regulation authorities to draw more attention to Type II agency conflict in future law enforcement.

\section{AUTHOR INFORMATION}

Chiraz Ben Ali, Associate Professor of Accounting at IPAG Business School, France. E-mail: chiraz.benali@ipag.fr

\section{REFERENCES}

1. Ali, A., Chen, T.-Y., \& Radhakrishnan, S. (2007). Corporate disclosures by family firms. Journal of Accounting and Economics, 44(1-2), 238-286.

2. Attig, N., Fong, W. F., Gadhoum, Y., \& Lang, L. H. P. (2006). Effects of large shareholding on information asymmetry and stock liquidity. Journal of Banking and Finance, 30, 2875-2892.

3. Baek, H. Y., Johnson, D. R., \& Kim, J. W. (2009). Managerial ownership, corporate governance, and voluntary disclosure. Journal of Business \& Economic Studies, 15(2), 44-61.

4. Baker, B., West, L., Cartwright, B., \& Nysenbaum, B. (2011). Liability of outside directors in SEC enforcement actions. Corporate Governance Advisor, 19(3), 16-21.

5. Bantel, K. A., \& Jackson, S. E. (1989). Top management and innovations in banking: Does the composition of the top team make a difference? Strategic Management Journal, 10, 107-124.

6. Barako, D. G., Hancock, P., \&. Izan, H. Y (2006). Factors influencing voluntary corporate disclosure by kenyan companies. Corporate Governance: An International Review, 14(2), 107-125.

7. Barros, C. P., Boubaker, S., \& Hamrouni, A. (2013). Corporate governance and voluntary disclosure in France. Journal of Applied Business Research, 29(2), 561-578.

8. Bassett, M., Koh, P.-S., \& Tutticci, I. (2007). The association between employee stock option disclosures and corporate governance: Evidence from an enhanced disclosure regime. The British Accounting Review, 39(4), 303-322.

9. Boubaker, S., \& Sami, H. (2011). Multiple large shareholders and earnings informativeness. Review of Accounting and Finance, 10(3), 246-266. 
10. Chau, G., \& Gray, S. J. (2010). Family ownership, board independence and voluntary disclosure: Evidence from Hong Kong. Journal of International Accounting, Auditing and Taxation, 19(2), 93-109.

11. Chau, G. K., \& Gray, S. J. (2002). Ownership structure and corporate voluntary disclosure in Hong Kong and Singapore. The International Journal of Accounting, 37(2), 247-265.

12. Chen, C. J. P., \& Jaggi, B. (2000). Association between independent non-executive directors, family control and financial disclosures in Hong Kong. Journal of Accounting and Public Policy, 19, 285-310.

13. Chen, S., Chen, X. I. A., \& Cheng, Q. (2008). Do family firms provide more or less voluntary disclosure? Journal of Accounting Research, 46(3), 499-536.

14. Cheng, E. C. M., \& Courtenay, S. M. (2006). Board composition, regulatory regime and voluntary disclosure. The International Journal of Accounting, 41(3), 262-289.

15. Eisenberg, T., Sundgren, S., \& Wells, M. T. (1998). Larger board size and decreasing firm value in small firms. Journal of Financial Economics, 48(1), 35-54.

16. Faccio, M., \& Lang, L. H. P. (2002). The ultimate ownership of Western European corporations. Journal of Financial Economics, 65(3), 365-395.

17. Fama, E. F., \& Jensen, M. C. (1983). Separation of ownership and control. Journal of Law and Economics, 26, 301-325.

18. Fan, J. P. H., \& Wong, T. J. (2002). Corporate ownership structure and the informativeness of accounting earnings in East Asia. Journal of Accounting and Economics, 33(3), 401-425.

19. Fan, J. P. H., \& Wong, T. J. (2005). Do external auditors perform a corporate governance role in emerging markets? Evidence from East Asia. Journal of Accounting Research, 43(1), 35-72.

20. Forker, J. J. (1992). Corporate governance and disclosure quality. Accounting \& Business Research, 22(86), 111-124.

21. Garcia-Meca, E., \& Sanchez-Ballesta, J. P. (2010). The association of board independence and ownership concentration with voluntary disclosure: A meta-analysis. European Accounting Review, 19(3), 603-627.

22. Gelb, D. S. (2000). Managerial ownership and accounting disclosures: An empirical study. Review of Quantitative Finance \& Accounting, 15(2), 169-185.

23. Gul, F. A., Kim, J.-B., \& Qiu, A. A. (2010). Ownership concentration, foreign shareholding, audit quality, and stock price synchronicity: Evidence from China. Journal of Financial Economics, 95(3), 425-442.

24. Ho, J. L., \& Fei, K. (2013). Auditor choice and audit fees in family firms: Evidence from the S\&P 1500. Auditing, 32(4), 71-93.

25. Ho, S., \& Wong, K. S. (2001). A study of the relationship between corporate governance structures and the extent of voluntary disclosure. Journal of International Accounting, Auditing \& Taxation, 10(2), 139-156.

26. Hope, O.-K., Langli, J. C., \& Thomas, W. B. (2012). Agency conflicts and auditing in private firms. Accounting, Organizations \& Society, 37(7), 500-517.

27. Hope, O.-K., \& Thomas, W. B. (2008). Managerial empire building and firm disclosure. Journal of Accounting Research, 46(3), 591-626.

28. Iatridis, G., \& Alexakis, P. (2012). Evidence of voluntary accounting disclosures in the Athens stock market. Review of Accounting and Finance, 11(1), 73-92.

29. Jensen, M. C. (1993). The modern industrial revolution, exit, and the failure of internal control systems. Journal of Finance, 48(3), 831-880.

30. John, K., \& Senbet, L. W. (1998). Corporate governance and board effectiveness. Journal of Banking \& Finance, 22(4), 371-403.

31. Johnson, S., La Porta, R., Lopez-de-Silanes, F., \& Shleifer, A. (2000). Tunneling. American Economic Review, 90(2), 22-27.

32. Khalil, S., Magnan, M. L., \& Cohen, J. R. (2008). Dual-class shares and audit pricing: Evidence from the Canadian markets. Auditing, 27(2), 199-216.

33. La Porta, R., Lopez-de-Silanes, F., Shleifer, A., \& Vishny, R. (1999). The quality of government. Journal of Law, Economics, and Organization, 1(1), 222-279.

34. La Porta, R., Lopez-de-Silanes, F., Shleifer, A., \& Vishny, R. (2000). Investor protection and corporate governance. Journal of Financial Economics, 58(1-2), 3-27.

35. Labelle, R., \& Schatt, A. (2005). Structure de propriété et communication financière des entreprises françaises. Finance - Contrôle - Stratégie, 8(3), 77-104.

36. Lakhal, F. (2007). Ownership structure and voluntary disclosures: The case of french listed firms. Corporate Ownership \& Control, 5(1), 131-138. 
37. Lang, M. H., \& Lundholm, R. (1993). Cross-sectional determinants of analyst ratings of corporate disclosures. Journal of Accounting Research, 31(2), 246-271.

38. Liu, M., \& Magnan, M. (2011). Self-dealing regulations, ownership wedge, and corporate valuation: International evidence. Corporate Governance: An International Review, 19(2), 99-115.

39. Mak, Y. T., \& Li, Y. (2001). Determinants of corporate ownership and board structure: Evidence from Singapore. Journal of Corporate Finance, 7(3), 235-256.

40. Marston, C. L., \& Shrives, P. J. (1991). The use of disclosure indices in accounting research: A review article. British Accounting Review, 23(3), 195-210.

41. Molz, R. (1988). Managerial domination of boards of directors and financial performance. Journal of Business Research, 16(3), 235-249.

42. Morck, R., Scheifer, A., \& Vishny, R. W. (1988). Management ownership and market valuation. Journal of Financial Economics, 20(1), 293-315.

43. Nagar, V., Nanda, D., \& Wysocki, P. (2003). Discretionary disclosure and stock-based incentives. Journal of Accounting and Economics, 34(1-3), 283-309.

44. Nelson, J., Gallery, G., \& Percy, M. (2010). Role of corporate governance in mitigating the selective disclosure of executive stock option information. Accounting \& Finance, 50(3), 685-717.

45. Patelli, L., \& Prencipe, A. (2007). The relationship between voluntary disclosure and independent directors in the presence of a dominant shareholder. European Accounting Review, 16(1), 5-33.

46. Schmid, M. M. (2009). Ownership structure and the separation of voting and cash flow rights-evidence from Switzerland. Applied Financial Economics, 19(18), 1453-1476.

47. Shleifer, A., \& Vishny, R. W. (1986). Large shareholders and corporate control. Journal of Political Economy, 94(3, Part 1), 461-488.

48. Villalonga, B., \& Amit, R. (2006). How do family ownership, control and management affect firm value? Journal of Financial Economics, 80(2), 385-417.

49. Williamson, O. E. (1983). Organization form, residual claimants, and corporate control. Journal of Law and Economics, 26(2), 351-366.

50. Xie, B., Davidson Iii, W. N., \& DaDalt, P. J. (2003). Earnings management and corporate governance: The role of the board and the audit committee. Journal of Corporate Finance, 9(3), 295.

51. Yermack, D. (1996). Higher market valuation of companies with a small board of directors. Journal of Financial Economics, 40(2), 185-211.

52. Yoshikawa, T., \& Rasheed, A. A. (2009). Family control and ownership monitoring in family-controlled firms in Japan. Journal of Management Studies, 47(2), 274-295. 


\section{NOTES}

